\title{
Row orientation effects on Syrah grapevine performance during winter growing season ${ }^{1}$
}

\author{
Claudia Rita de Souza*(D), Renata Vieira da Mota, Camila Pinheiro Carvalho Silva, \\ Ricardo Henrique Paulino Raimundo, Fernanda de Paula Fernandes, Isabela Peregrino \\ $10.1590 / 0034-737 X 201966030004$
}

\begin{abstract}
The sunlight and heating effects on leaves and grapes are directly influenced by row orientation in vineyards. Row orientation studies have not been addressed under double pruning management, a technique used to transfer the wine grape harvest from wet summer to dry winter season in Brazilian Southeast. Effects of grapevine row orientation (north/south - NS and east/west - EW) of vertically trellised and shoot positioned Vitis vinifera L. Syrah grafted onto 1103 Paulsen were investigated in the South of Minas Gerais State. The vegetative vigor was increased in NS oriented vines, probably due to high photosynthesis as suggested by the highest leaf starch accumulation. The leaf and stem water potential were slight affected by row orientation. NS orientation increased the cluster weight, but cluster number and yield per vine were not affected by treatments. Berries from NS oriented vines also showed the highest values of anthocyanins and total phenols. Under NS orientation there was a reduction on tartaric acid and soluble sugar in berries probably diluted by increased cluster weight. This study showed that vineyard under NS orientation improved grapevine vigor and promoted better phenolic maturity in wine grapes harvested during the winter season than EW orientation.
\end{abstract}

Keywords: Vitis vinifera; vineyard design; double pruning; vigor; wine grape quality.

\section{INTRODUCTION}

Vine growth, yield, grape and wine quality attributes are strongly influenced by the macro (regional climate) and microclimate (climatic variability at the fruit zone) conditions of the vineyards (Van Leeuwen \& Seguin, 2006). The temperature and solar radiation pattern within wine growing region, influenced by altitude and latitude, and the sunlight exposure and temperature at canopy and cluster zone have a great impact on the yield and quality performance of a vineyard. It is well known that photosynthetic rate, transpiration and water status are directly affected by solar radiation and temperature regimes throughout growing season (Williams, 1996; Bertamini \& Nedunchezhian, 2004; Chaves et al., 2016). Light and temperature may also have a synergistic effect on bud fruitfulness, anthesis, fruit set and berry growth (Williams, 1996; Vasconcelos et al., 2009). Furthermore, the level of sugars, organic acids, anthocyanins and aromatic compounds in grapes is also dependent on microclimatic conditions around cluster zone (Spayd et al., 2002; Pereira et al., 2006; Scafidi, et al., 2013; Barreiro et al. 2015). High berry temperature in sun exposed cluster can increase anthocyanin content (Spayd et al., 2002; Haselgrove et al., 2008; Tarara et al., 2008), but it can be also degraded by extreme temperature (Mori et al 2007; Haselgrove et al., 2008). The total acidity tends to be lower and $\mathrm{pH}$ higher in hot environment or sun exposed cluster as compared to berries from shaded conditions or cool regions (Jackson \& Lombard, 1993; Spayd et al., 2002; Sadras et al., 2013).

Submitted on February 27 th, 2019 and accepted on June 24th, 2019.

${ }^{1}$ This work is part of the studies developed by the research team of EPAMIG. It is a result of partnership between public (EPAMIG/FAPEMIG/CNPq) and private (Stella Valentino Ltda Winery) sectors. This study was partially funded by FAPEMIG and CNPq.

Empresa de Pesquisa Agropecuária de Minas Gerais (EPAMIG), Núcleo Tecnológico de Uva e Vinho, 37780 000, Caldas, Minas Gerais, Brazil. crsouza@epamig.br; motarv@epamig.br: k_mila_pinheiro@hotmail.com; ricardohenrique553@gmail.com; fernandapaula_fernandes@outlook.com; isabela.peregrino@epamig.br

*Corresponding author: crsouza@epamig.br 
Sunlight and heating effects on leaves and grapes at vineyards are directly influenced by row orientation being an important factor determining canopy microclimate and thus berry composition. In general, most of the vineyards around the world are North-South (NS) oriented. NS rows, by receiving morning sun on one side and afternoon sun on the other, are better displayed to maximize light interception as compared to East - West (EW) rows (Hunter et al., 2016; Campos et al., 2017). On the other hand, EW orientated rows can capture largest portion of total radiation in the cluster zone from soil reflected radiation and leaves of EW orientated vines can also show higher $\mathrm{CO}_{2}$ assimilation, stomatal conductance and transpiration than NW orientation as showed by Hunter et al., (2016). However, the reduced light interception in EW row orientation may also have a negative impact on growth and yield as compared to NS direction (Chorti et al., 2018).

Although the choice of row orientation is mainly based on the best sunlight interception by the vine canopies, in some vineyard locations the topography and erosion potential should be also taken into account to minimize the soil degradation. In these sites, the slope is more determining factor for vineyard design than sunlight interception. It is also important to highlight that most of studies about row orientations effects on vine growth and grape composition were carried out under Spring and Summer climatic conditions. Over the last fifteen years, the harvest of wine grape was changed from wet Summer to dry Winter by double pruning management in order to improve the wine quality in the Brazilian Southeast. Low rainfall and high thermal amplitude during the AutumnWinter seasons are more favorable to synthesis and accumulation of sugar and phenolic compounds in berries from grapevines growing under warm temperate and tropical climate zones as already showed by Mota et al., (2010); Favero et al., (2011); Regina et al., (2011). Under this new vineyard management and in a high-altitude region, the row orientation studies have not been addressed. This study investigated the effects of north south and east - west row orientation on vigor, vine status, yield and grape composition of Syrah growing under Autumn-Winter season in South of Minas Gerais State.

\section{MATERIALAND METHODS}

The experiment was carried out in 2016 in a nonirrigated commercial vineyard located in Andradas (2203’20.57" S 46³2'28.19" W, altitude of $1002 \mathrm{~m}$ ), South of Minas Gerais State. Based on historical climatic data provided by the website pt.climate-data.org, the experimental site is in warm temperate zone with dry Winter and hot Summer, defined as Cwa type, according to the
Köppen classification (Alvares et al., 2014). Historically, the annual rainfall for this region is $1579 \mathrm{~mm}(<200 \mathrm{~mm}$ during the winter) whereas the annual mean, maximum and minimum temperature is $20^{\circ} \mathrm{C}, 26.3{ }^{\circ} \mathrm{C}$ and 13.8 , respectively).

Two adjacent vineyard blocks, with moderate slope of 9\%, were North - South (NS) and East - West (EW) oriented and planted in 2007 using 'Syrah', clone 174 ENTAV-INRA, grafted onto 1103 Paulsen. In both blocks, the vines were spaced to a fixed distance of $2.5 \times 1.0 \mathrm{~m}$, trained on a vertical shoot position and spur pruned on a bilateral Royat Cordon. The double pruning management was applied to allow grape harvest during the Winter. The first pruning was done in September 2015 to in duce the vegetative cycle where all bunches should be removed because the purpose was not to harvest during the summer, but to have the inflorescence primordia differentiated into latent buds. In March 2016, the yield pruning was done in lignified shoots to promote the productive cycle during the Autumn-Winter season.

During the ripening period (July and August), at 9:30 $\mathrm{h}$ and 13:00 h, the vine water status was measured by leaf $\left(\Psi_{\text {leaf }}\right)$ and stem $\left(\Psi_{\text {stem }}\right)$ water potential using pressure chamber model 3005 (Soil-moisture Equipement Corp., Santa Barbara, CA, USA). The $\Psi_{\text {leaf }}$ measurements were done on six exposed and mature leaves per treatment. To determine $\Psi_{\text {stem }}$, the leaves were bagged $1 \mathrm{~h}$ prior to measurements using plastic sheet and aluminum foil (Choné et al. 2001).

The starch concentration was assessed on dried and powered samples of mature and sun exposed leaves (six leaves per treatment). The leaves were sampled at midday in the same dates used for vine water status measurements. The starch was extracted from $100 \mathrm{mg}$ sample using $80 \%$ (v/v) ethanol $\left(80^{\circ} \mathrm{C}, 20 \mathrm{~min}\right)$ and centrifuged $(9,160 \mathrm{x} \mathrm{g}, 15$ $\mathrm{min})$. This process was repeated three times. The extracted pellet was dried overnight at room temperature and was hydrolyzed through incubation at $75{ }^{\circ} \mathrm{C}$ for $1 \mathrm{~h}$ with Termamyl® $120 \mathrm{~L}$ (diluted 1:500 in water), followed by incubation at $50{ }^{\circ} \mathrm{C}$ for 1 hour with amyloglucosidase 300 $\mathrm{L}$ (28 unit $\mathrm{mL}-1$, in sodium acetate buffer, $\mathrm{pH} 4.8$ ). The starch content was quantified from released glucose by colorimetric method at $450 \mathrm{~nm}$ using glucose oxidase/ peroxidase/ABTS assay (Bergmeyer, 1974). Starch content was calculated as glucose multiplied by conversion factor of 0.9 (Cordenunsi \& Lajolo 1995).

Total leaf chlorophyll content was also determined in August (08/08 and 29/08). The fresh leaf discs of $3.14 \mathrm{~cm}^{2}$ were collected from eight vines per treatment (one leaf disc per vine) and stored at $-20{ }^{\circ} \mathrm{C}$ until analysis. The chlorophyll pigments were extracted with $80 \%$ acetone and the concentration was determined spectrofotometrically according to Arnon (1949). 
Berry temperature was measured during the ripening period in different positions of the clusters from sun exposed side of the canopy (twenty berries per row orientation) at beginning of the morning (9:00h). Measurements of berry temperature were performed by insertion of thermometer with stainless steel penetration probe (Hanna instruments) into the berry center. At harvest (August 30 ${ }^{\text {th }}$ ), the yields components (cluster number and weight and yield per vine) were measured on fifteen vines per treatment. Ten replicates of 100 berries per treatment were used to evaluate the chemical analyses (soluble solids, $\mathrm{pH}$ and titratable acidity. Soluble solids ( ${ }^{\circ}$ Brix) were determined by refractometry, titratable acidity by tritation with $0.1 \mathrm{NaOH}$ and $\mathrm{pH}$ using a pHmeter. Skins were weighed separately, frozen in liquid $\mathrm{N}_{2}$ and stored at -80 ${ }^{\circ} \mathrm{C}$ until analysis. Total anthocyanins and total phenolics in the berries skins were analyzed as described by Mota et al. (2011).

Malic and tartaric acids were extracted from the acid fraction obtained after grape juice separation by use of anion exchange resin Bio Rex 5 (Bio Rad Labs) (McCord et al., 1984). Chromatographic analysis was performed by Agilent 1260 Infinit HPLC system using DAD detector (210nm) and Supelcogel C-610H column (Supelco, $30 \mathrm{~cm} \mathrm{x}$ $7.8 \mathrm{~mm}$ ) maintained at $30^{\circ} \mathrm{C}$. As a mobile phase, phosphoric acid $(0.5 \% \mathrm{v} / \mathrm{v})$ was used at a flow rate of $0.5 \mathrm{~mL} \mathrm{~min}^{-1}$.

Fresh weight of removed shoot at pruning (pruning weight) was used as a measure of vegetative vigor of the vine during the growing season. One month after winter harvest, all shoots per vine (six vines per treatment) were pruned and weighted. All leaves were removed from shoots before weighting.

Statistical data analysis was performed by analyses of variance (ANOVA). Tukey's HSD tests were used to determine the statistically significant differences between treatment means, using the STATISTICA software (ver. 5.0, Statsoft, Inc. Tulsa, OK, USA).

\section{RESULTS AND DISCUSSION}

The impact of row orientation on vine photosynthetic metabolism was investigated through leaf chlorophylls and starch content (Table 1). The chlorophylls were also used as nitrogen status indicator since it is a nitrogen compound and they are closely related to greenness of the leaf (Taiz \& Zeiger, 2004; Huerta et al., 2013). Although there were no differences on chlorophyll concentrations, the leaf starch content was significantly higher in NS oriented vines $(\mathrm{p}<0.05)$, in both sampling dates, suggesting that carbon assimilation more than nitrogen status was more affected by vineyard design.

It is well known that sunlight induces stomatal aperture, activates chlorophylls and some photosynthetic enzymes to convert the assimilated carbon into sucrose in cytosol and starch in chloroplast (Taiz \& Zeiger, 2004; Geigenberger, 2011). The illumination advantage of northsouth rows during midmorning as compared to East-West rows probably favored the stomatal conductance and photosynthetic rate increasing the starch accumulation at midday in NS oriented vines. Since berry temperature can increase linearly with sunlight exposure (Bergqvist $e t$ al 2001), the highest berry temperature observed in sun exposed side of the canopy under NS orientation suggest an increased solar radiation interception by NS vines at beginning of the morning (Figure 1).

As also showed by some authors, the photosynthetic active radiation (PAR) absorption by NS oriented vines trained under vertical shoot position (VSP) is greater during the morning as compared to EW orientation (Hunter

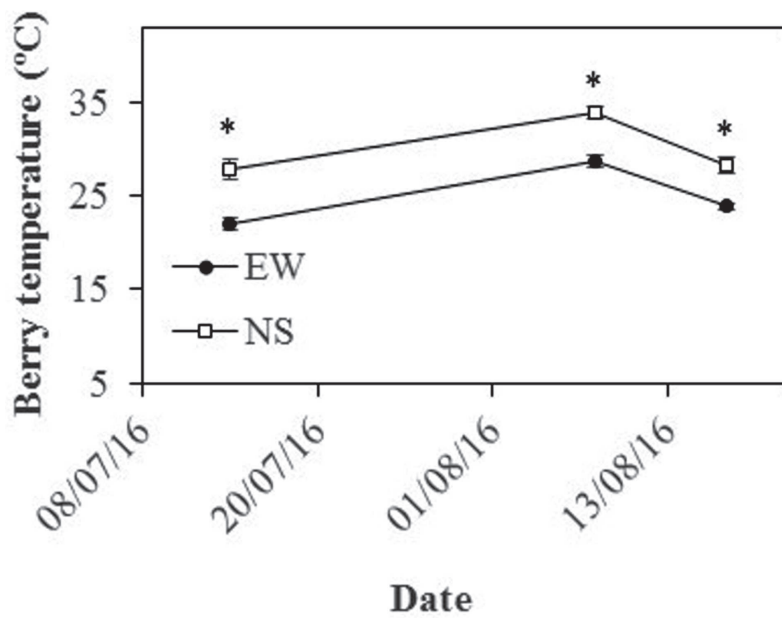

Figure 1: Berry temperature in sun exposed side from EW and NS oriented rows. The measurements were done during ripening period at beginning of the morning. Each value is the mean \pm standard error of 20 replicates. Asterisks $(*)$ means significant differences between treatments as determined by Tukey's test $(\mathrm{p}<0.05)$.

Table 1: Total leaf chlorophyll, leaf starch and pruning weight of Syrah under North/South (NS) and East/West (EW) orientation during autumn-winter. Each value is the mean \pm standard error of six replicates. Same letter does not differ significantly between treatments as determined by Tukey's test $(\mathrm{p} \geq 0.05)$

\begin{tabular}{|c|c|c|c|c|c|}
\hline \multirow[b]{2}{*}{ Treat } & \multicolumn{2}{|c|}{ Chlorophyll (mg m$\left.{ }^{-2}\right)$} & \multicolumn{2}{|c|}{ Leaf starch $\left(\mathrm{mg} \mathrm{gdw}^{-1}\right)$} & \multirow{2}{*}{$-\frac{\text { Pruning weight }(\mathrm{kg})}{03 / 10 / 2016}$} \\
\hline & 08/08/2016 & $29 / 08 / 2016$ & $14 / 07 / 2016$ & 08/08/2016 & \\
\hline $\mathrm{NS}$ & $315.94 \pm 4.34 \mathrm{a}$ & $295.89 \pm 15.20 \mathrm{a}$ & $22.18 \pm 1.63 \mathrm{a}$ & $21.33 \pm 1.38 \mathrm{a}$ & $0.271 \pm 0.023 \mathrm{a}$ \\
\hline EW & $299.99 \pm 7.15 \mathrm{a}$ & $279.13 \pm 8.72 \mathrm{a}$ & $14.16 \pm 1.02 \mathrm{~b}$ & $17.05 \pm 0.60 \mathrm{~b}$ & $0.201 \pm 0.016 b$ \\
\hline
\end{tabular}

Rev. Ceres, Viçosa, v. 66, n.3, p. 184-190, mai/jun, 2019 
et al., 2016; Campos et al 2017). On the other hand, Hunter et al. (2016) also showed that, although the highest average of photosynthesis and stomatal conductance had been observed in leaves of EW oriented vines, NS and NW - SE orientations showed the most uniform canopy photosynthesis. In our study, the highest leaf starch accumulation in NS oriented vines at midday suggests greater photosynthetic rates during the morning due to more light interception in this row direction. Although photosynthetic activity was not measured in this study, the leaf starch contents can be considered as an integrative measurement of photosynthesis since part of diurnal assimilated carbon is stored as starch in the light period and remobilized during the night to support metabolism and growth in the whole plant. (Taiz \& Zeiger, 2004; Geigenberger, 2011). Furthermore, the vine vegetative vigor was also increased $(\mathrm{p}<0.05)$ under NS direction as showed by values of pruning weight measured at the end of the growing season (Table 1). Despite vegetative growth is a result of interaction among several physiological processes such as photosynthesis, long-distance transport, respiration, water relations, assimilates partitioning and mineral nutrition; there is a positive correlation between vine vigor and photosynthetic rates (Keller, 2010). Thus, the increased leaf starch content and pruning weight suggest a better photosynthetic performance in NS oriented vines induced by the largest sunlight exposure of leaf area.

Vine water status was slightly affected by row direction. In general, both $\Psi$ leaf and $\Psi$ stem did not vary much between treatments in most of measurements (Figure 2). However, at midday, vines under EW oriented showed the lowest values (more negative) $(\mathrm{p}<0.05)$ of $\Psi$ leaf and $\Psi$ stem in July $14^{\text {th }}$ and August $16^{\text {th }}$, respectively (figure 2 A, D). Probably, at midday during the Winter, the sun azimuth was already mostly in favor of northerly exposed side of the canopy increasing leaf transpiration in EW treatment. At beginning of the morning, when the East side of NS row is more sun exposed as compared to EW rows, the $\Psi$ leaf showed the highest values in NS oriented vines only in middle of August (Figure $2 \mathrm{C}$ ).

The $\Psi$ leaf values ranged from -1.26 to $-2.27 \mathrm{MPa}$ whereas $\Psi$ stem ranged from -0.57 to $-0.98 \mathrm{MPa}$. According to the literature, although values of $\Psi$ leaf can be considered as indicator of severe water stress, the measured values of $\Psi$ stem is considered favorable during ripening period (Van Leeuwen et al., 2009). These variables depend on climatic parameters, but the $\Psi$ stem is more sensitive indicator of vine water stress because it reflects more the interaction between soil water availability and the whole vine water potential than Yleaf (Choné et al. 2001; Van Leeuwen et al., 2009). Furthermore, visible symptoms of severe water stress such as yellowing or wilting of basal leaves were not observed in both row orientations. The $\Psi$ stem values revealed a moderate water stress during the ripening period, which it is favorable for improvement of berry quality (Van Leeuwen et al., 2009).

The row orientation effects on yield components were also subtle (Table 2). Cluster weight increased in NS oriented vines, but the number of cluster and yield per vine were not affected by treatments.

However, Hunter et al. (2017) observed that EW oriented vines showed higher berry volume and mass due to higher vine water status in this treatment whereas Giacosa et al. (2015) did not observe influence of row orientation on berry and skin weights. In our study, probably the better vine water status of NS oriented vines, as showed by the highest values of $\Psi$ leaf and $\Psi$ stem (Figure 2 A, D) contributed to increase the weight of cluster. Furthermore, the highest vegetative vigor of vines under NS orientation may have partially shaded the cluster reducing the berry transpiration.

Berries from NS oriented vines also showed the highest values of anthocyanins and total phenols and the lowest values of total soluble sugars and tartaric acid (Tables 2 and 3). Tartaric and malic acids comprise up to $90 \%$ of organic acids in pre-veraison grapes. During ripening, acid degradation occurs due to respiration of malic acid, which increases with temperature. The levels of tartaric acid per berry remains relatively stable but its concentration decreases due to dilution induced by increasing in berry volume (Rösti et al., 2018).

The reduction on tartaric acid and sugar observed in NS oriented berries was probably due to dilution caused by increased cluster weight in these vines. However, the effect of sample processing on tartaric acid amount as mentioned by Rösti et al. (2018) may not be discarded since must was freezed prior to organic acids analysis and no treatment was performed to prevent or resolubilize tartaric acid lost by precipitation reactions mainly with potassium ions.

The differences between treatments on sugar concentrations were lower than one ${ }^{\circ}$ Brix which have no significant impact on wine alcoholic degree. There was no difference in malic acid concentration between treatments. Malic acid accumulation and degradation in grape berries is temperature dependent. Moderate temperatures $\left(20-25^{\circ} \mathrm{C}\right)$ favor malic accumulation while degradation occurs above $38^{\circ} \mathrm{C}$ (Keller, 2010). In the winter season, there were no differences between treatments in sun exposure clusters in the afternoon when high temperatures were registered $\left(39.5\right.$ and $39.6{ }^{\circ} \mathrm{C}$, respectively for $\mathrm{N} / \mathrm{S}$ and $\mathrm{E} / \mathrm{W}$ row orientation). Moreover, the highest berry temperature observed in NS vines did not impaired the malic acid composition since the values were lower than $34^{\circ} \mathrm{C}$ during the morning (Figure 1). 
As reported by several authors, the anthocyanins, tanins and flavonoids are also highly influenced by temperature, sunlight and its interactive effects (Spayd et al. 2002; Pereira et al., 2006; Tarara et al. 2008; Scafidi, et al., 2013). Dokoozlian (2009) observed that north-south rows intercepted up to $15 \%$ more sunlight compared to east-west rows. According to Bowen (2009) the accumulation of anthocyanins and other phenolics in berries is dependent on light exposure under moderate temperatures $\left(20-25^{\circ} \mathrm{C}\right)$ by the activation of the enzyme phenylalanine ammonia lyase (PAL). Temperatures above 30-35 ${ }^{\circ} \mathrm{C}$, otherwise, impairs the accumulation of anthocyanis. In general, the phenolic compounds synthesis is favored by the best sun cluster exposure in NS oriented vines than in other vineyard directions (Chorti et al., 2018). In our study, the best balance between

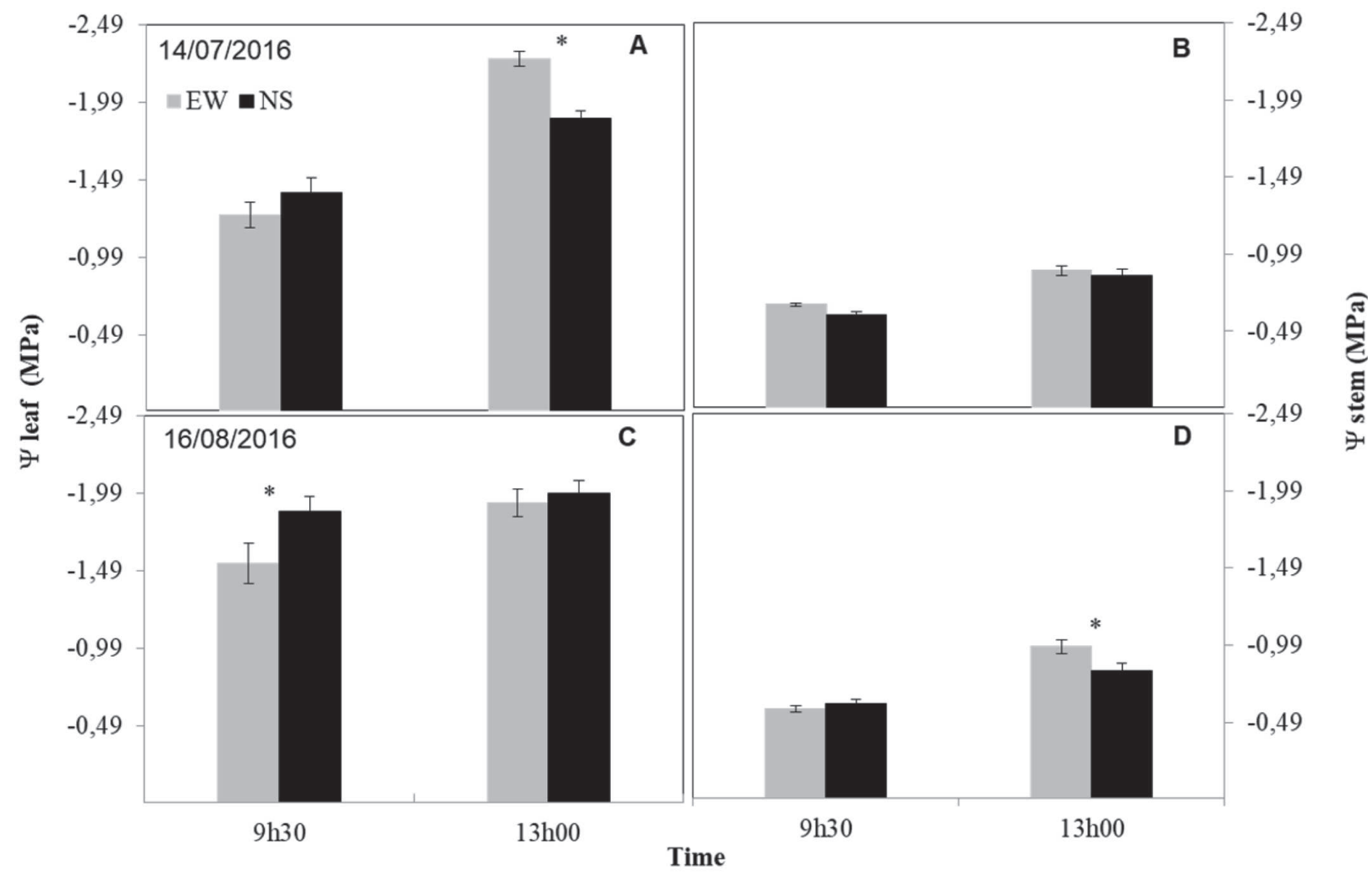

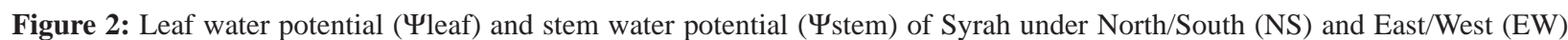
orientation in 14/07/2016 (A, B) and 16/08/2016 (C, D). Each value is the mean \pm standard error of six replicates. Asterisks (*) means significant differences between treatments as determined by Tukey's test $(\mathrm{p}<0.05)$.

Table 2: Yield components (cluster number and yield per vine and cluster weight) and grape composition (pH, total soluble sugar SS and tritatable acidity - TA) of Syrah under North/South (NS) and East/West (EW) orientation at winter harvest. Each value is the mean \pm standard error of ten replicates. Same letter does not differ significantly between treatments as determined by Tukey's test $(\mathrm{p} \geq 0.05)$

\begin{tabular}{lcccccc}
\hline Treat & $\begin{array}{c}\text { Cluster } \\
\text { number }\end{array}$ & $\begin{array}{c}\text { Cluster } \\
\text { weight }(\mathbf{g})\end{array}$ & $\begin{array}{c}\text { Yield } \\
\left(\mathbf{k g ~ v i n e}^{-1}\right)\end{array}$ & pH & $\begin{array}{c}\text { S S } \\
\left({ }^{\circ} \text { Brix }\right)\end{array}$ & $\begin{array}{c}\text { TA } \\
\left(\mathbf{g ~ L}^{-1}\right)\end{array}$ \\
\hline NS & $14.87 \pm 0.76 \mathrm{a}$ & $130.54 \pm 8.45 \mathrm{a}$ & $1.97 \pm 0.18 \mathrm{a}$ & $3.53 \pm 0.01 \mathrm{a}$ & $21.39 \pm 0.06 \mathrm{a}$ & $5.60 \pm 0.03 \mathrm{a}$ \\
EW & $17.40 \pm 1.54 \mathrm{a}$ & $104.88 \pm 6.39 \mathrm{~b}$ & $1.89 \pm 0.24 \mathrm{a}$ & $3.55 \pm 0.01 \mathrm{a}$ & $21.68 \pm 0.04 \mathrm{~b}$ & $5.38 \pm 0.05 \mathrm{a}$ \\
\hline
\end{tabular}

Table 3: Anthocyanins, total phenols, malic acid and tartaric acid of Syrah grapes from North/South (NS) and East/West (EW) oriented vines at winter harvest. Each value is the mean \pm standard error of ten replicates for phenolic compounds and five replicates for organic acids. Same letter does not differ significantly between treatments as determined by Tukey's test $(p \geq 0.05)$

\begin{tabular}{lcccc}
\hline Treat & $\begin{array}{c}\text { Anthocyanins } \\
\left(\mathbf{m g ~ g ~ b e r r y ~}^{-1}\right)\end{array}$ & $\begin{array}{c}\text { Total Phenols } \\
\left(\mathbf{m g ~ g ~ b e r r y} \mathbf{1}^{\mathbf{1}}\right)\end{array}$ & $\begin{array}{c}\text { Malic acid } \\
\left(\mathbf{g ~ L}^{-\mathbf{1}}\right)\end{array}$ & $\begin{array}{c}\text { Tartaric acid } \\
\left(\mathbf{g ~ L}^{-\mathbf{1}}\right)\end{array}$ \\
\hline NS & $1.38 \pm 0.03 \mathrm{a}$ & $4.07 \pm 0.08 \mathrm{a}$ & $2.14 \pm 0.08 \mathrm{a}$ & $4.22 \pm 0.26 \mathrm{a}$ \\
EW & $1.16 \pm 0.04 \mathrm{~b}$ & $3.34 \pm 0.12 \mathrm{~b}$ & $2.25 \pm 0.03 \mathrm{a}$ & $5.26 \pm 0.15 \mathrm{~b}$ \\
\hline
\end{tabular}

Rev. Ceres, Viçosa, v. 66, n.3, p. 184-190, mai/jun, 2019 
vegetative and reproductive parts may also be involved in the increased anthocyanins and total phenols observed in NS oriented vines. Although there is no information about crop load (fruit weight per unit pruning weight or leaf area) adjustment under Autumn Winter cultivation, the vines under NS orientation seemed to be better balanced than EW oriented vines. Furthermore, the best photosynthetic performance of NS oriented vines, as suggested by accumulated leaf starch, could have contributed to the phenolic ripeness since the precursors of these compounds are synthetized in leaves and berries (Bogs et al., 2005). These polyphenols are very important because of their contribution to appearance (color), flavor and astringency of wines.

\section{CONCLUSIONS}

The row orientation had more influence on vegetative vigor and grape composition than on yield of Syrah grapevines.

Our results showed that vineyard under North - South orientation increased grapevine vigor and promoted a better phenolic maturity in wine grapes harvested during the winter season as compared to East - West orientation. Under this perspective, if there is no topographical limitation, the North - South design should be chosen by viticulturists in new establishments of vineyard under double pruning management.

\section{REFERENCES}

Alvares CA, Stape JL, Sentelhas PC, Gonçalves LM \& Sparovek G (2014) Koppen's climate classification map for Brazil. Meteorologische Zeitschrift, 22:711-728.

Arnon DI (1949) Copper enzymes in isolated chloroplasts: polyphenol oxidase in Beta vulgaris. Plant Physiology, 24:0115 .

Barreiro CG, Otero RR, Grande BC \& Gándara JS (2015) Wine aroma compounds in grapes: A Critical Review, 55:202-218.

Bergmeyer HU (1974) Methods of Enzymatic Analysis. New York, Academic Press. USA. 760p.

Bergqvist J, Dokoozlian N \& Ebisuda N (2001) Sunlight exposure and temperature effects on berry growth and composition of Cabernet Sauvignon and Grenache in the central San Joaquin Valley of California. American Journal of Enology and Viticulture, 52:01-07.

Bertamini M \& Nedunchezhian N (2004) Photosynthetic responses for Vitis vinifera plantas grown at different photon flux densities under field conditions. Biologia Plantarum, 49:149-152.

Bogs J, Downey MO, Harvey JS, Ashton AR, Tanner GJ \& Robinson SP (2005) Proanthocyanidin synthesis and expression of genes encoding leucoanthocyanidin reductase and anthocyanidin reductase in developing grape berries and grapevine leaves. Plant Physiology, 139:652-663.

Bowen P (2009) Foundations of Canopy Management: The Contributions of Dr. Mark Kliewer. In: Dokoozlian N \& Wolpert J (Eds.) Recent Advances in Grapevine Canopy Management. Davis, University of California. p.01-05.
Chaves MM, Costa JM, Zarrouk O, Pinheiro C, Lopes CM \& Pereira JS (2016) Controlling stomatal aperture in semi-arid regions. The dilemma of saving water or being cool? Plant Science, 251:54-64.

Campos I, Neale CMU \& Calera A (2017) Is row orientation a determinant factor for radiation interception in row vineyards? Australian Journal of Grape and Wine Research, 23:77-86.

Choné X, Van Leeuwen C, Dubourdieu D \& Gaudillère JP (2001) Stem water potential is a sensitive indicator of grapevine water status. Annals of Botany, 87:477-483.

Chorti E, Theocharis S, Boulokostas K, Kallithraka S, Kotseridis Y \& Koundouras S (2018) Row Orientation and Defoliation Effects on Grape Composition of Vitis vinifera L. Agiorgitiko in Nemea (Greece). Available at: https://www.e3s-conferences.org/articles/ e3sconf/pdf/2018/25/e3sconf_terroircongress2018_01039.pdf. Accessed on: February $21^{\text {st }}, 2019$.

Cordenunsi BR \& Lajolo FM (1995) Starch breakdown during banana ripening: Sucrose synthase and sucrose phosphate syntase behavior. Journal of Agricultural and Food Chemistry, 43:347351.

Dokoozlian N (2009) Integrated canopy management: A Twenty year evolution in California. In: Dokoozlian N \& Wolpert J (Eds.) Recent Advances in Grapevine Canopy Management. Davis, University of California. p.43-52.

Favero AC, Amorim DA, Mota RV, Soares AM, Souza CR \& Regina MA (2011) Double-pruning of 'Syrah' grapevines: a management strategy to harvest wine grapes during the winter in the Brazilian Southeast. Vitis, 50:151-158.

Geigenberger P (2011) Regulation of starch biosynthesis in response to a fluctuating environment. Plant Physiology, 155:1556-1577.

Giacosa S, Marengo F, Guidoni S, Rolle L \& Hunter JJ (2015) Anthocyanin yield and skin softening during maceration, as affected by vineyard row orientation and grape ripeness of Vitis vinifera L. cv. Shiraz. Food Chemistry, 174:08-15.

Haselgrove L, Botting D, VanHeeswijck R, Hoj PB, Dry PR, Ford C \& Iland PG (2008) Canopy microclimate and berry composition: the effect of bunch exposure on the phenolic composition of Vitis vinifera L. cv. Shiraz grape berries. Australian Journal of Grape and Wine Research, 6:141-149.

Huerta RFM, Gonzales RGG, Medina LMC, Pacheco IT, Olivarez JP \& Velazquez RVO (2013) A review of methods for sensing the nitrogen status in plants: advantages, disadvantages and recent advances. Sensors, 13:10823-10843.

Hunter JJ, Volschenk CG \& Zorer R (2016) Vineyard row orientation of Vitis vinifera L. cv. Shiraz/101-14 Mgt: Climatic profiles and vine physiological status. Agricultural and Forest Meteorology, 228:104-119.

Hunter JJ, Volschenk CG \& Booyse M (2017) Vineyard row orientation and grape ripeness level effects on vegetative and reproductive growth characteristics of Vitis vinifera L. cv. Shiraz/ 101-14 Mgt. European Journal of Agronomy, 84:47-57.

Jackson DI \& Lombard PB (1993) Environmental and management practices affecting grape composition and wine quality - a review. American Journal of Enology and Viticulture, 44:409430.

Keller M (2010) The science of grapevines: anatomy and physiology. London, Elsevier. 377p.

McCord JD, Trousdale E \& Ryu DDY (1984) An improved sample preparation procedure for the analysis of major organic compounds in grape must and wine by high performance liquid chromatography. American Journal of Enology and Viticulture, 35:28-29. 
Mori K, Goto-Yamamoto N, Kitayama M \& Hashuzume K (2007) Loss of anthocyanins in red-wine grape under high temperature. Journal of Experimental Botany, 58:1935-1945.

Mota RV, Favero AC, Silva CPC, Purgatto E, Shiga TM \& Regina MA (2011) Wine grape quality of grapevines grown in the cerrado ecoregion of Brazil. Journal International des Sciences de la Vigne et du Vin, 45:101-109.

Mota RV, Silva CPC, Favaero AC, Purgatto E, Shiga TM \& Regina MA (2010) Composição físico-química de uvas para vinho fino em ciclos de verão e inverno. Revista Brasileira de Fruticultura, 32:1127-1137.

Pereira GE, Gaudillere JP, Pieri P, Hilbert G, Maucourt M, Deborde C, Moing A \& Rolin D (2006) Microclimate influence on mineral and metabolic profiles of grape berries. Journal of Agriculture and Food Chemistry, 54:6765-6775.

Regina MA, Mota RV, Souza CR \& Favero AC (2011) Viticulture for fine wines in Brazilian southeast. Acta Horticulturae, 910:113-120

Rösti J, Schumann M, Cleroux M, Lorenzini F, Zufferey V \& Rienth M (2018) Effect of drying on tartaric acid and malic acid in Shiraz and Merlot berries. Australian Journal of Grape and Wine Research, 24:421-429.

Sadras VO, Petrie PR \& Moran MA (2013) Effects of elevated temperature in grapevine. II Juice $\mathrm{pH}$, titratable acidity and wine sensory atributes. Australian Journal of Grape and Wine Research, 19:107-115.
Scafidi P, Pisciotta A, Patti D, Tamborra P, Di Lorenzo R \& Barbagallo MG (2013) Effect of artificial shading on the tannin accumulation and aromatic composition of the Grillo cultivar (Vitis vinifera L.). BMC Plant Biology, 13:01-11.

Spayd SE, Tarara JM, Mee DL \& Fergunson JC (2002) Separation of sunlight and temperature effects on the composition of Vitis vinifera cv. Merlot berries. American Journal of Enology and Viticulture, 53:171-182.

Taiz L \& Zeiger E (2004) Plant Physiology. $3^{\text {th }}$ ed. Porto Alegre, Artmed.720p.

Tarara JM, Lee J, Spayd SE \& Scagel CF (2008) Berry temperature and solar radiation alter acylation, proportion, and concentration of anthocyanin in Merlot grapes. American Journal of Enology and Viticulture, 59:236-246.

Van Leeuwen A \& Seguin G (2006) The concept of terroir in viticulture. Journal of Wine Research, 16:01-10.

Van Leeuwen A, Tregoat O, Choné X, Bois B, Pernet D \& Gaudièllere JP (2009) Vine water status is a key factor in grape ripening and vintage quality for red Bordeaux wine. How can it be assessed for vineyard management purposes? Journal International des Sciences de la Vigne et du Vin, 43:121-134.

Vasconcelos MC, Greven M, Winefield CS, Trought MC \& Raw V (2009) The flowering process of Vitis vinifera: a review. American Journal of Enology and Viticulture, 60:411-434.

Williams LE (1996) Grape. In: Zamski E \& Schaffer AA (Eds.) Photoassimilates distribution in plants and crops. source - sink relationships. New York, Marcel Dekker. p.851-881. 